\title{
POLYURETHANE DEGRADING BACTERIA ISOLATED FROM DECAYED TEAK WOOD (Tectona grandis Linn. f.)
}

\author{
Farah Aldila*1, Ari Susilowati $^{2}$, Ratna Setyaningsih ${ }^{3}$
}

Received : April 16, 2019

Accepted : September 17, 2019

DOI: 10.15575/biodjati.v4i2.4525

1,2,3Bioscience Program, Pascasarjana, Universitas Sebelas Maret; Jl. Ir. Sutami No. 36A Surakarta, Central Java, Indonesia 57126, Telp./Fax. +62-815-42096292

e-mail:

*1aldilafarah@gmail.com 2 arisusilowati@staff.uns.ac.id ${ }^{3}$ ratnas@staff.uns.ac.id

*Corresponding author
Abstract. Polyurethane is a class of polymers characterized by their substantial tensile strength and high melting points which enables them to be extremely durable. Despite its xenobiotic origin, polyurethane has been found susceptible to biodegradation by microorganisms. The main object of this research was to investigate polyurethane degradation by the bacterium isolated from decayed teak wood (Tectona grandis Linn.f.). Polyurethane degrading bacteria were isolated using selective medium in the form of LB (Luria Bertani) with the addition of $0.3 \%$ Impranil. Bacterial biodegradation activities shown by the changes of polyurethane structure analyzed by FT-IR spectroscopy. The bacterial identification was carried out based on observations on the morphological characteristics of the colonies, cell morphology and sequences of 16S rRNA encoding genes. One of the potential isolate that successfully isolated was K9, which demonstrates the disappearance of the $1735 / \mathrm{cm}$ peak of the characteristic function urethane in the FT-IR analysis. Analysis of the 16S rRNA encoding gene showed that the potential isolate having $98 \%$ similarity index to Bacillus safensis strain FO-36b. The activity shown by the isolate suggests that the bacteria could be a promising agent for polyurethane degradation.

Keywords: biodegradation, polyurethane, teak wood

\section{Citation}

Aldila, F., Susilowati, A. \& Setyaningsih, R. (2019). Polyurethane Degrading Bacteria Isolated from Decayed Teak Wood (Tectona grandis Linn. f.). Jurnal Biodjati, 4(2), 225-235

\section{INTRODUCTION}

Polyurethane is a polymer containing a urethane moiety in its repeating unit. Although it may contain urethane groups, other moieties, such as urea, ester, ether or an aromatic may also be included (Bayer, 1947). According to Howard (2002), polyurethane is a synthetic polymer that is formed by the reaction of condensation polymerization between polyisocyanate and polyol which having intramolecular urethane bonds. Urethanes are derivatives of carbamic acids which exist only in the form of their esters. Polyurethanes have gradually replaced earlier polymers in various areas including marine and aircraft coatings and foams in car seats and furnishings. Santerre et al. (2005) reported that polyurethane is considered as one of the most bio and blood compatible materials known in the medical area. They have played a major role in the development of many medical devices due to their structural properties, blood and tissue compatibility and resistance to macromolecular oxidation hydrolysis and calcification.

Polyurethane widely used as a base material in various industries, and is found just about everywhere in modern life. Some of the 


\section{JURNAL BIDDJATI}

http://journal.uinsgd.ac.id/index.php/biodjati

applications of that versatile polymer include foams, elastomers, paints, fabric coatings, adhesives, and sealants. In order to develop bioremediation techniques for refractory waste, such as polyurethane, an investigation of new organisms and knowledge on how these compounds are degraded is needed. Nair \& Kumar (2007) have reported that Bacillus pumillus NMSN-1d isolated from polyurethane contaminated water are known to have the ability to degrade polyurethane when grown in high salinity medium. Shah et al. (2013) have also identified polyurethane degradation activity by Bacillus subtilis MZA-75 and Pseudomonas aeruginosa MZA-85 and detected the hidrolysis of polyurethane ester bonds by esterase. Nakkabi et al. (2015b; 2015c) have reported similiar activity by Bacillus subtilis and Pseudomonas stutzeri isolated from cedar wood. Polyurethane degrading bacteria that have been isolated from natural sources (Nair \& Kumar, 2007; Shah et al., 2013; Nakkabi et al., 2015a; 2015b), indicates that there are potential reservoirs of polyurethane degrading organisms widespread in the environment.

In this context, we considered studying biodegradation of polyurethane (Impranil DL 1380) by bacteria isolated from decayed teak wood. Indonesia is a country with a very rich biological natural resources, the Indonesian tropical forests rank 3rd in the world (Indrawati \& Rizki, 2017) with teak wood (Tectona grandis) as one of the best quality forests products (Inspiring, 2018). Teak wood is a woody plant which has complex lignocellulose. The main components in lignocellulose materials are cellulose, hemicellulose and lignin. All three form a complex chemical bond that becomes the basic material of plant cell walls (Hermiati et al., 2010). Carpita \& Mc Cann (2000) stated that the ester bond is one that makes up lignocellulose. Microorganisms that could live on the decayed teak wood are thought to be able to degrade ester bonds from complex lignocellulose in their substrate, so it is expected that these microorganisms have the ability to degrade polyurethane polymers, which mainly composed of ester bonds.

\section{MATERIALS AND METHODS}

\section{Material Collection and Preparation}

The specific polyurethane used in the study was Impranil DL 1380, which was obtained in the form of liquid (Covestro, Germany). Impranil is suitable for common textile coating processes in the fields of sports, clothing, fashion articles, technical items, and general protective equipment. Impranil DL 1380 is solid polymer dispersed in water. The solid part consists of a linear aliphatic diisocyanate and aliphatic polyester (Covestro, 2018). The bacterial strain was isolated from decayed teak wood collected from Mojosongo village, Boyolali Regency, Central Java.

\section{Bacterial Degradation Activities of Polyu- rethane}

Purified bacteria were inoculated into a solid selective LB medium (This medium is made by mixing $0.05 \mathrm{~g}$ of yeast extract, $0.1 \mathrm{~g}$ of $\mathrm{NaCl}, 0.1 \mathrm{~g}$ of tryptone and $0.3 \mathrm{ml}$ of Impranil DL 1380 into $100 \mathrm{ml} \mathrm{dH2O}$ ), then incubated for 7 days at $37^{\circ} \mathrm{C}$. Bacteria that can degrade polyurethanes will show a clear zone around the colony (Nakkabi et al., 2015a). IR-spectrophotometer analysis was carried out to determine changes in polyurethane structure. The sample used was taken from a liquid culture that had been incubated for 10 days. Samples were centrifuged for 1 minute at $4,200 \mathrm{~g}$ to remove bacterial material, and then evaporated at $37^{\circ} \mathrm{C}$ to form film. The polyurethane film was then analyzed using an IR-spectrophotometer by using deionized water as the background spectrum (Rusell et al., 


\section{JURNAL BIDDJATI}

http://journal.uinsgd.ac.id/index.php/biodjati

2011). The control polyurethane (Impranil DL 1380) should show a large absorption peak at $1735 \mathrm{~cm}^{-1}$, due to the presence of ester bonds in the polyurethane polymer. The loss of peak at the absorption of $1735 \mathrm{~cm}^{-1}$ indicates the degradation of polyurethane due to the changes of ester bonds that make it.

\section{Morphological Bacterial Characterization}

Bacterial characterization was carried out based on observations on the morphological characteristics of colonies and cells, by culturing the isolates on selective solid LB medium and then observing the colour, shape and edge of the colony. The cell morphology identified by gram staining method. The first step was heat-fixing bacteria on the glass slide, crystal violet was added and left for 1 minute. The sample was then pressed with 1 drop of iodine and left for 30 seconds before rinsed with $95 \%$ alcohol. Safranin was added and left for 30 seconds before rinsed with distilled water. Observation of the bacteria was carried out using a light microscope. Purple bacterial cells show gram-positive, while the red bacterial cells show gram-negative (Sagita, 2016).

\section{Molecular Bacterial Identification}

Molecular identification was based on sequences of $16 \mathrm{~S}$ rRNA encoding genes. For molecular identification, the genomic DNA was extracted using PrestoTM gDNA mini bacteria kit (Geneaid). The gene was then amplified by PCR thermal cycler (Applied BioSystem) using bacterial primers $63 \mathrm{f}\left(5^{\prime}-\mathrm{CAG}\right.$ GCC TAA CAC ATG CAA GTC-3') as primer forward and 1387r (5'-GGG CGG WGT GTA CAA GGC-3') as reverse primer (Marchesi et al., 1998). The PCR mixture contained $1 \mu \mathrm{M}$ of each primer, $25 \mu \mathrm{L}$ of My Taq Red Mix buffer (2X) (Bioline) and ddH2O. To this mixture, 2 $\mu \mathrm{L}$ of the DNA template was added. The total reaction volume was $50 \mu \mathrm{L}$. The reaction was amplified in a Thermal Cycler using the following programs: $95^{\circ} \mathrm{C}$ for $1 \mathrm{~min} ; 30$ cycles of $95^{\circ} \mathrm{C}$ for $15 \mathrm{~s}, 55^{\circ} \mathrm{C}$ for $15 \mathrm{~s}, 72^{\circ} \mathrm{C}$ for $10 \mathrm{~s}$ followed by a final extension step of $72^{\circ} \mathrm{C}$ for 5 min (My Taq protocol, Bioline). The PCR product was then checked by electrophoresis. The electrophoresis (Bio-Rad) used 1\% agarose at a voltage of 70 volts for 45 minutes. DNA visualization was carried out trough UV transilluminator and documented using gel documentation (Bio-Rad). The amplified DNA was then sequenced in Singapore's $1^{\text {st }}$ base laboratory. Sequencing was performed by using Big Dye terminator cycle sequencing kit v.3.1 (Applied BioSystems). The similarity of the sequences was determined by comparing the sequences with those available in the online databases provided by the National Centre for Biotechnology Information (NCBI) using the BLAST search program (http://www.ncbi.nlm.nih.gov/BLAST). Determination of the potential bacteria identity based on Bosshard et al. (2003), with the following criteria, the percentage of similarity $\geq$ 99\% indicates the same species, the percentage of similarity between $\geq 95 \%-<99 \%$ indicates the same genus, and the percentage of similarity $<95 \%$ indicates the same family.

\section{Potential Bacteria Relationship Based on 16S rRNA Encoding Gene}

The potential bacterial relationship between isolates in this study with some of the closest potential species based on the $16 \mathrm{~S}$ rRNA encoding gene was presented in the form of a phylogenetic tree. The construction of phylogenetic tree was prepared using the Molecular Evolutionary Genetics Analysis (MEGA) program with the Neighbor-Joining (NJ) method (Kumar et al., 2015). 


\section{JURNAL BIDDJATI}

http://journal.uinsgd.ac.id/index.php/biodjati

\section{RESULTS AND DISCUSSION}

\section{Bacterial Isolation}

The bacterial isolation produced 12 bacterial isolates in which only two of them had the ability to degrade polyurethane, as presented in Table 1. This article will review Isolate K9 due to its activity to degrade polyurethane.

The small proportion of isolated potential bacteria obtained (Table 1) was due to the substrate difference given in this research and what occurs in nature. Bacteria that live in decayed teak wood substrate utilize the lignocellulotic component to carry out their lives, while the isolated ones rely on synthetic polyurethane (Impranil DL 1380) substrates in growing media.
Both lignocellulose of the teak wood and Impranil DL 1380 are complex polymers that are difficult to decompose, but they differ in shape and characteristics. Lignocellulose composes of a variety of complex bonds, such as esters which bind to various aromatic groups, lignins and polysaccharides, thus forming a structure that is very sturdy and difficult to decompose (Carpita \& Mc Cann, 2000), while the Impranil DL 1380 composes of linear polyurethane with high molecular weight aliphatic polyester chains. That difference of characteristics between decayed teak wood and Impranil DL 1380 substrates certainly provide a very different habitat for the bacteria, thus limit its growth.

Table 1. Bacteria isolated from decayed teak wood

\begin{tabular}{ccc}
\hline Source & Isolate & Zone of clearance \\
\hline Teak wood & K 1 & - \\
K 2 & - \\
K 3 & - \\
K 4 & - \\
K 5 & - \\
K 6 & - \\
K 7 & - \\
K 8 & - \\
K 9 & + \\
K10 & + \\
K11 & - \\
K12 & - \\
\hline
\end{tabular}

Description : $(+)=$ forming a clear zone around the colony; $(-)=$ does not forming clear zone around the colony

Degradation of Polyurethane in a Solid Medium

Polyurethane degradation activity of isolate $\mathrm{K} 9$ was indicated by its ability to form clear zones on selective agar medium (Figure 1).

The zone of clearance around the growing culture, shows the structural changes of Aldila et al. polyurethane in the substrate (Figure 1). The selective solid LB medium shows opaque, and becomes transparent upon bacterial degradation. The research is in line with Nakkabi et al. (2015b) which revealed that the clear zones at the selective medium formed due to the presence of polyurethane hydrolysis. 


\section{JURNAL BIDDJATI}

http://journal.uinsgd.ac.id/index.php/biodjati

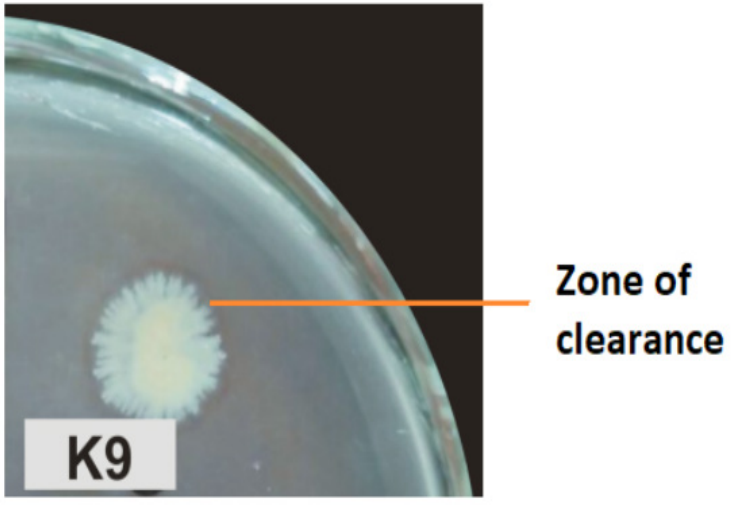

Figure 1. Growth of bacteria (Isolate K9) on a LB plate supplemented with $0.3 \%$ impranil DL 1380 . The colony produce zone of clearance showing polyurethane degradation

\section{Degradation of Polyurethane in a Liquid Medium}

Polyurethane degradation activity was continued by growing potential isolates on liquid medium (Figure 2).

The selective liquid LB medium was opaque and when it was incubated with the K9 isolate, it showed changes in opacity, and gradually became transparent. The changes in the medium from opaque to transparent indicated changes in the polyurethane structure present in the medium. The changes in opacity of the liquid medium is in line with the research conducted by Nakkabi et al. (2015a; 2015b; 2015c), reporting the degradation activity of polyurethane by Bacillus safensis, Bacillus subtilis and Pseudomonas stutzeri isolated from Cedar wood, where one of the parameters was indicated by degradation in liquid Impranil LB medium, from the original opaque to transparent. Akatsu et al. (1998) also reported similar activities by Comamonas acidovorans TB-35, which produce polyurethane esterase to degrade polyurethane. Analysis of water soluble PUR breakdown products revealed diethylene glycol and adipic acid as probably the main metabolites. These observations implied that an esterase-like enzyme plays at least some role in PUR degradation by TB-35. The Comamonas acidovorans TB-35 degrades polyurethane through two stages of reaction, hydrophobic adsorption on the surface of the polyurethane then hydrolyzes the ester bonds

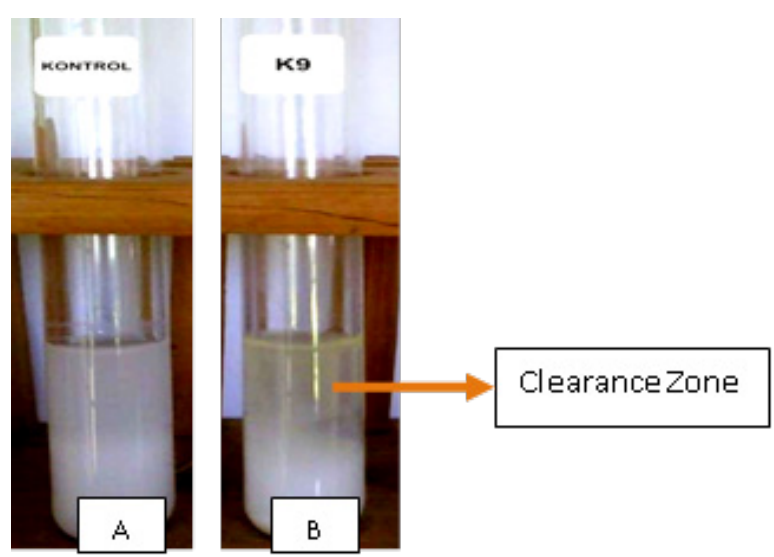

Fig. 2. Impranil DL 1380 degradation in liquid LB medium with the concentration $0,3 \%$ after 10 days of incubation; $\mathrm{A}=$ Control without bacteria; $\mathrm{B}=$ incubation with bacteria (Isolate K9)

\section{FT-IR Analysis of the Degradation of Pol- yurethane}

Polyurethane samples of Impranil DL 1380 displayed a large absorption peak at $1735 / \mathrm{cm}$ representing carbonyl group of esters $(\mathrm{C}(\mathrm{O})-\mathrm{O})$ in the polyurethane polymer (Kristianingrum, 2011). The absorption of the polyurethane sample (control) shown in Figure 3. A progressive reduction in the relative intensity of the peak at $1735 / \mathrm{cm}$ was observed and was accompanied by more subtle changes at another wave number (Figure 4).

By the time the culture has become visually transparent, there was a complete disappearance of the absorbance peak at $1735 / \mathrm{cm}$ (Figure 4). The peak at $1.735 / \mathrm{cm}$ representing carbonyl group of esters disappeared in the FT-IR spectrum of the test sample. Besides, the control polyurethane showed sharp peaks in the area of 3389/cm (Figure 3), whereas the treatment polyurethane showed a shift to $3444 / \mathrm{cm}$ and the peak broadened (Figure 4) due to the presence of free hydroxyl group. 


\section{JURNAL BIDDJATI}

http://journal.uinsgd.ac.id/index.php/biodjati

Kristianingrum (2011) stated that the absorption peak that occurs in the $3700-3100 / \mathrm{cm}$ region caused by stretching vibrations of $\mathrm{O}-\mathrm{H}$ or $\mathrm{N}-\mathrm{H}$, and the presence of hydrogen bonds leading the peak to be broadened.

The changes of peak also occurs in the area of $1172 / \mathrm{cm}$ (Figure 3) which absent in the treated sample (Figure 4), indicating the dissapearance of $\mathrm{C}-\mathrm{O}$. The loss of the $\mathrm{C}=\mathrm{O}$ and $\mathrm{C}-\mathrm{O}$ groups, as well as the formation of hydroxyl groups $(\mathrm{O}-\mathrm{H})$ indicate that ester hydrolysis took place as a result of bacterial treatment. The FT-IR spectrum of the treated polyurethane supports the idea of the involvement of bacterial esterases in the degradation of polyurethane. A similar study has been investigated by Nakkabi et al. (2015a) which reported the bacterial degradation of polyurethane samples using FT-IR and observed subtle decline in the peak representing ester functionality $(1735 / \mathrm{cm})$ with gradual loss of opacity in the liquid medium supplemented by polyurethane.

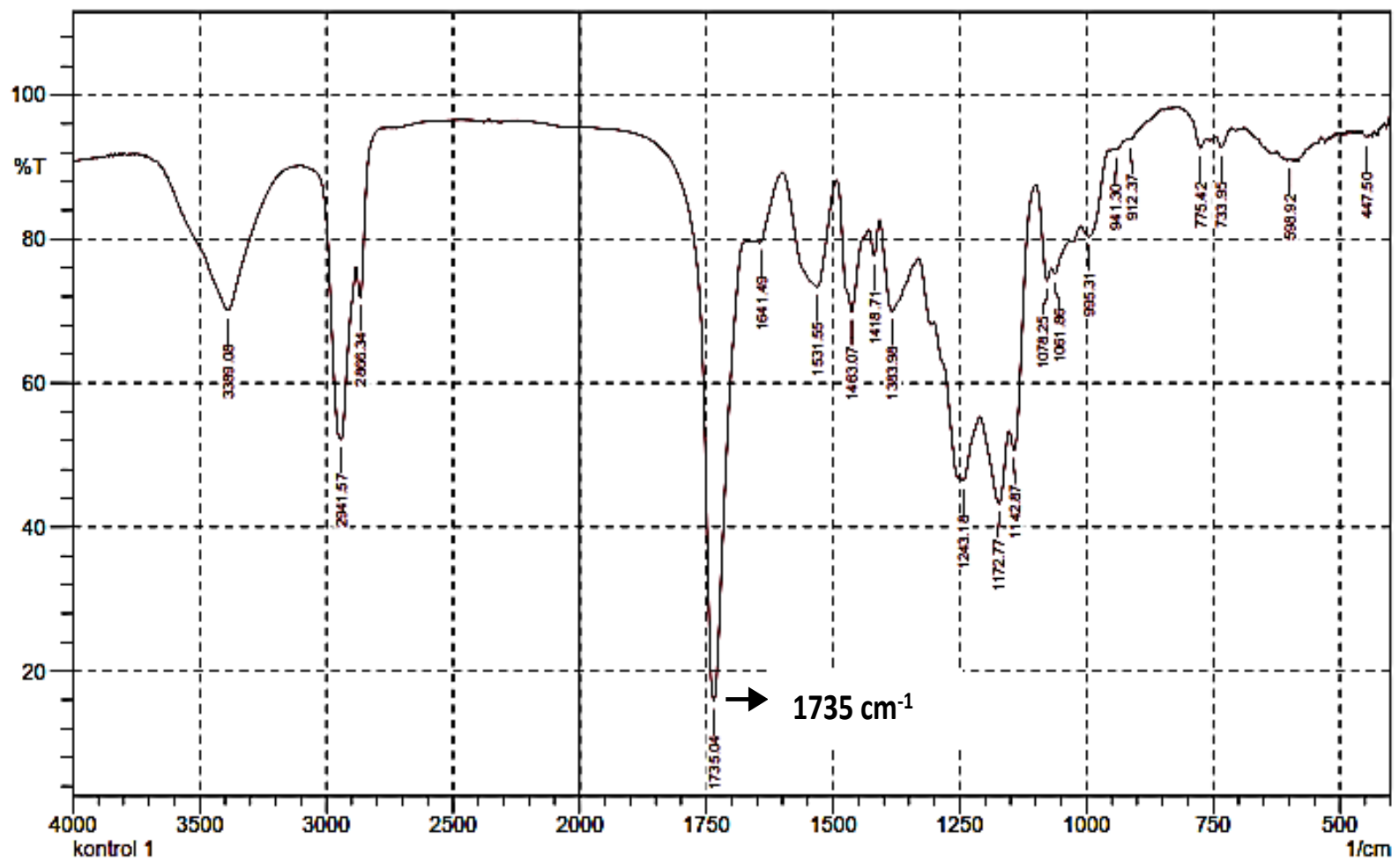

Figure 3. Infrared spectra of polyurethane liquid medium containing $0.3 \%$ of Impranil DL 1380 without bacterial incubation. The absorbtion area of $1735 \mathrm{~cm}-1$ indicate the presence of ester group. 


\section{JURNAL BIDDJATI}

http://journal.uinsgd.ac.id/index.php/biodjati

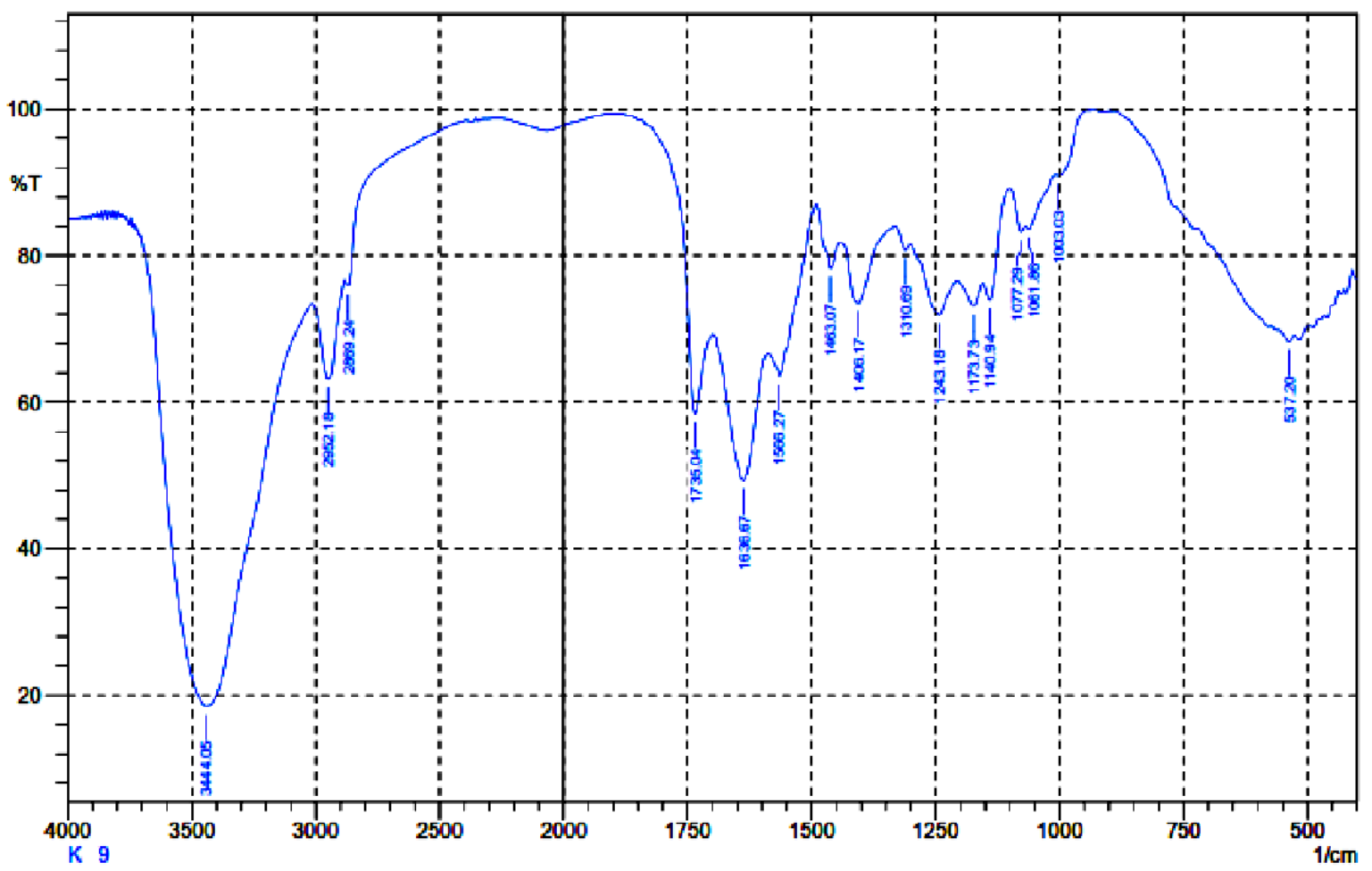

Figure 4. Infrared spectra of polyurethane liquid medium containing $0.3 \%$ of Impranil DL 1380 taken after 10 days of incubation with the potential bacteria. The absorbtion area of $1735 / \mathrm{cm}$ dissapeared.

\section{Bacteria Identity}

$\mathrm{K} 9$ isolate is a gram-positive bacteria with coccobacilli cells (Table 3 ) and opaque milky white-colored colony. It has irregular shape, umbonate and toothed margin (serrate) (Table 2).

K9 isolate belongs to the group of gram-positive bacteria, where the bacterial cells were purple-coloured after being subjected to gram staining. Kurnia et al. (2016) stated that gram staining is an important step in the initial identification. This colouring method is based on the thickness of the bacterial cell wall layer, thus affecting the ability of the bacterial cell wall to maintain the main colouring used. $\mathrm{KOH}$ testing was done to confirm the result of gram staining. K9 isolate did not form mucus threads when was mixed with $3 \% \mathrm{KOH}$ solution, indicating that the isolate belongs to gram-positive bacteria.

The molecular characterization to identify K9 isolate was based on the 16S rRNA encoding gene. The amplicon of 16S rRNA encoding gene that has been analyzed by agarose gel electrophoresis showed that there was a size of approximately $1300 \mathrm{bp}$ (Fig. 5).

Table 2. Morphological characters of potential bacterial colonies

\begin{tabular}{cccccc}
\hline \multirow{2}{*}{ Isolate } & \multicolumn{5}{c}{ Morphology of the colony } \\
\cline { 2 - 5 } & Pigmentation & shape & Margin & Elevation & Optical character \\
\hline K9 & milky white & irregular & undulate & flat & opaque \\
\hline
\end{tabular}


Jurnal Biodjati 4(2):225-235, November 2019

\section{JURNAL BIDDJATI}

http://journal.uinsgd.ac.id/index.php/biodjati

Table 3. Cell morphology of the potential bacteria

\begin{tabular}{cccc}
\hline \multirow{2}{*}{ Isolate } & \multicolumn{2}{c}{ Cell morphology } & \multirow{2}{*}{$*$ KOH 3\% test } \\
\cline { 2 - 3 } & Shape & Gram & \\
\hline K9 & Coccobacilli & Positive & - \\
\hline
\end{tabular}

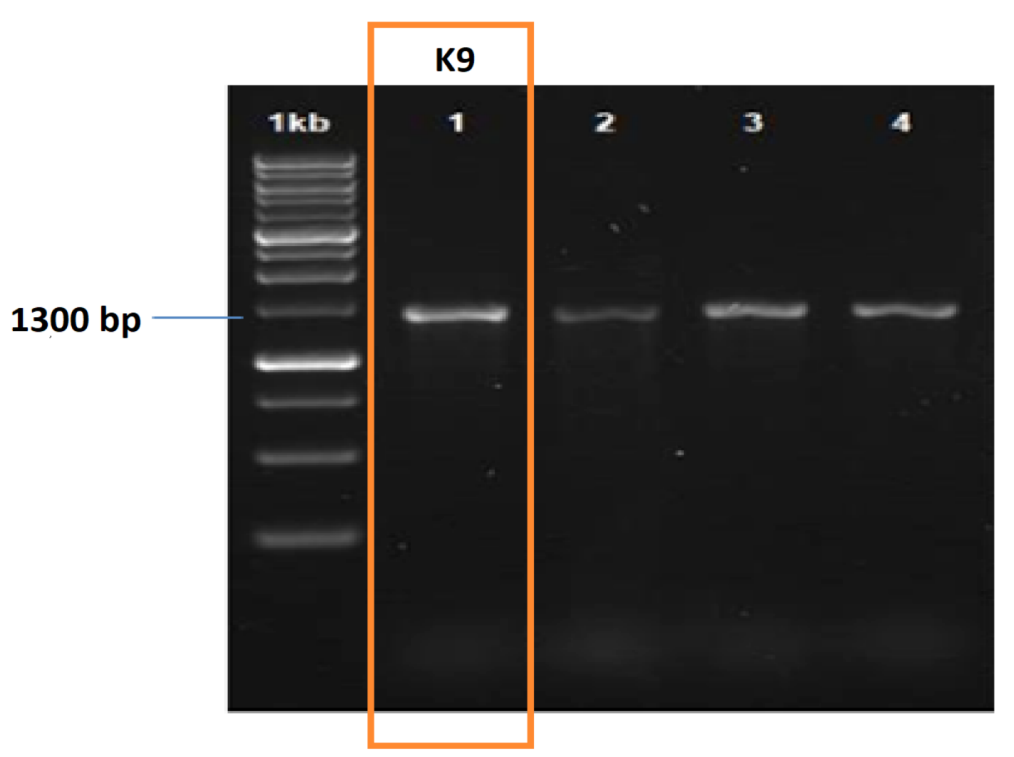

Figure 5. Electrophoregram amplicon of potential bacteria 16S rRNA encoding gene. The amplicon shows a size of approximately 1300 $\mathrm{bp}$

K9 isolate has the closest similarity to $B a$ cillus safensis strain FO-36b (NR_041794.1) based on the GeneBank data (Table 4). The index of similarity was $98 \%$, indicating the same genus of Bacillus. Bacillus is known as a cosmopolitan group of bacteria, which is resistant to various antiseptic compounds and has various enzymatic abilities (Hatmanti, 2000). The degradation of polyurethane by K9 Isolate has been chemically demonstrated by infrared spectroscopy, which shows the disappearance of the $1735 / \mathrm{cm}$ peak of the ester bonds. The loss of peak shows the hydrolysis of the ester bond in the urethane linkage along the chain. Hydrolysis of this function causes the degradation of polyurethane. The research is in line with Nakkabi et al. (2015a) which reported that the Bacillus safensis activities to degrade the polyurethane are by hydrolyzing the ester bonds.

Table 4. Similarities in the partial sequences of potential bacterial encoding genes 16s rRNA using the BLAST-N program

\begin{tabular}{ccccc}
\hline Isolate & Closest species & Query cover & \% Similarity & Accession number \\
\hline K9 & $\begin{array}{c}\text { Bacillus safensis strain } \\
\text { FO-36b }\end{array}$ & $96 \%$ & $98 \%$ & NR_041794.1 \\
\hline
\end{tabular}




\section{JURNAL BIDDJATI}

http://journal.uinsgd.ac.id/index.php/biodjati

\section{Potential Bacteria Relationship Based on 16S rRNA Encoding Gene}

The relationships between isolate $\mathrm{K} 9$ and some of the closest potential species based on the $16 \mathrm{~S}$ rRNA encoding gene were presented in the form of a phylogenetic tree (Figure 6).

Several species of the genus Bacillus are known to have the ability to degrade polyurethanes. Nakkabi et al. (2015a) have reported that Bacillus safensis isolated from decayed cedar wood known to have the abil- ity to degrade polyurethane polymer. Similar activities were detected by Nair \& Kumar (2017), who reported that Bacillus pumillus strain NMSN-1d isolated from polyurethane contaminated water known to have the ability to degrade polyurethane when grown in high salinity medium. Shah et al. (2013) have also reported the biodegradation activity of polyurethane by Bacillus subtilis strain MZA-7. The strain has the ability to hydrolyze the ester bonds in polyurethane polymer and convert it to $\mathrm{CO}_{2}$ and $\mathrm{H}_{2} \mathrm{O}$.

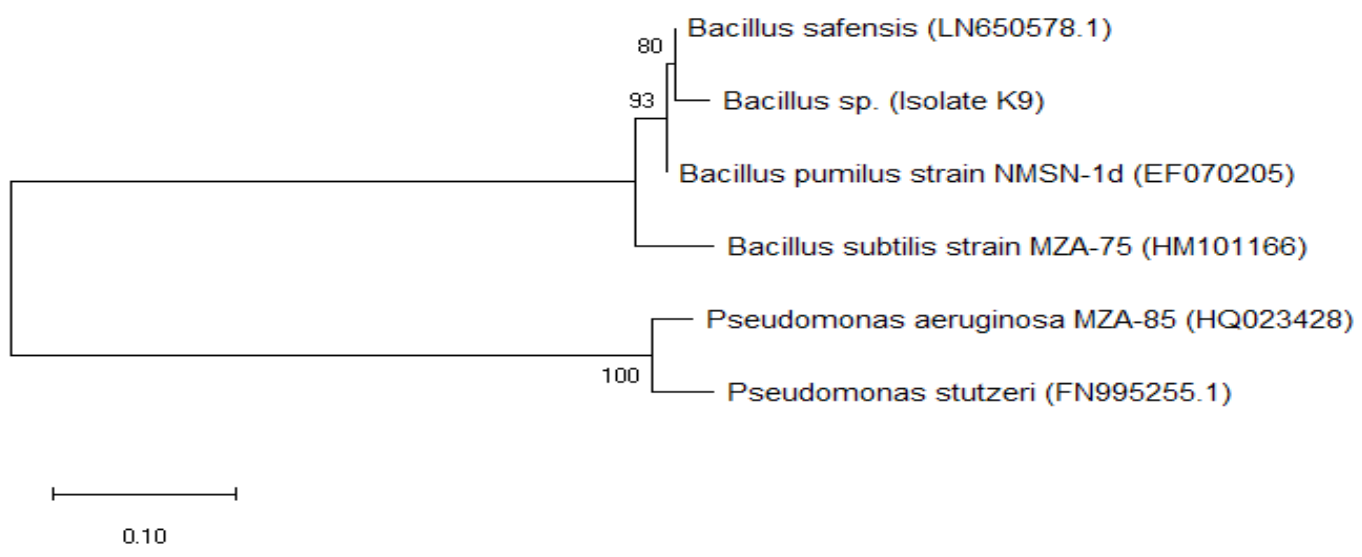

Figure 6. The phylogenetic tree of the potential bacteria with some of the closest potential bacteria species based on the 16S rRNA encoding gene by the Neighbor Joining (NJ) method.

\section{ACKNOWLEDGMENTS}

The authors would like to thank to Mrs. Fauziah (Covestro) for providing polyurethane (Impranil DL 1380) used in this study.

\section{REFERENCES}

Akutsu, Y, Nakajima-Kambe T, Onuma F \& Nakahara T. (1997). Determination of the Polyester Polyurethane Breakdown Products and Distribution of the Polyurethane Degrading Enzyme of $\mathrm{Co}$ mamonas acidovorans strain TB-35. $J$. Ferment. Bioeng., 83, 456-460.
Ambriyanto, K. S. (2010). Isolasi dan Karakterisasi Bakteri Aerob Pendegradasi Selulosa dari Serasah Daun Rumput Gajah (Pennisetum purpureum schaum). Skripsi. Institut Teknologi Sepuluh Nopember.

Bayer, O. (1947). Polyurethanes. Modern Plastics, 24, 149-152.

Bosshard, P.P., Abels, S., Zbinden, R., Ttger, E. C. B. \& Altwegg, M. (2003). Ribosomal DNA Sequencing for Identification of Aerobic Gram Positive Rods in the Clinical Labolatory (an 18 Month Evaluation). Journal of Clinical Microbiology, 41(9), $4234-4140$. 


\section{JURNAL BIDDJATI}

http://journal.uinsgd.ac.id/index.php/biodjati

Carpita, N \& McCann, M. (2000). The cell wall. Biochemistry and Molecular Biology of Plants. New Jersey: John Wiley and Sons Publishing.

Covestro. (2018). Dispersion. Germany: Covestro Deutschland AG.

Hermiati, E., Djumali, M., Sunarti, T. C., Suparno, O. \& Bambang, P. (2010). Pemanfaatan Biomassa Lignoselulosa Ampas Tebu untuk Produksi Bioetanol. Jurnal Litbang Pertanian, 29(4), 121-130.

Howard, G. T.(2002). Biodegradation of Polyurethane: a Review. Int. Biodeterior. Biodegrad, 49, 245-252.

Indrawati, I. \& Rizki, A. F. M. (2017). Potensi Ekstrak Buah Buni (Antidesma bunius L) sebagai Antibakteri dengan Bakteri Uji Salmonella thypimurium dan Bacillus cereus. Jurnal Biodjati, 2(2), 138148.

Inspiring. (2018). Daerah Penghasil Kayu Jati Terbesar di Indonesia. Retrieved from https://inspiring.id/daerah-penghasil-kayu-jati/.

Kristianingrum, S. (2015). Spektroskopi Infra Merah (Infrared Spectroscopy, IR). Yogyakarta: Pendidikan Kimia UNY.

Kurnia, K., Nina, H. S. \& Syafitri, J.(2016). Isolation of Heterotrophic Bacteria from Cibuntu pond, West Java and characterization of metal and acid resistance. AL-KAUNIYAH Journal of Biology, 9(2), 74-79.

Marchesi, J. R., Sato, T., Weightman, A. J., Martin, T. A., Fry, J. C., Hion, S. J. \& William G. W. (1998). Design and Evaluation of Useful Bacterium-Specific PCR Primers That Amplify Genes Coding for Bacterial 16S rRNA. Applied and Environmental Microbiology, 64(2), 795-799.

Nair, S \& Kumar, P.(2007). Molecular characterization of a lipase-producing Bacil- lus pumilus strain (NMSN-1d) utilizing colloidal water-dispersible polyurethane. World J Microbiol Biotechnol, 23, 1441-1449.

Nakkabi, A., Moulay, S., Saad I. \& Mohammed, F. (2015c). Biological Degradatoion of Polyurethane by Newly Isolated Microorganism. International Journal of Recent Advances in Multidisciplinary Research, 2(2), 222-225.

Nakkabi, A., Najim, I., Mohamed, D., Encarnación M. D. \& Mohammed, F. (2015b). Growth of Pseudomonas in polyurethane medium. IOSR Journal of Engineering (IOSRJEN), 5, 36-40.

Nakkabi, A., Sadiki, M., Fahim, M., Ittobane, N., Ibnsouda Koraichi, S., Barkai, H. \& El abed, S. (2015a). Biodegradation of Poly(ester urethane)s by Bacillus subtilis. Int. J. Environ. Res., 9(1), 157-162.

Russell, J. R. Huang, J., Anand, Kucera, K., Amanda, G., Kathleen, W. D., DaShawn, Justin J., Farrah, M. K., David, K., Daniel, H. M., Paul, A. M., Salvador, J., Marina, S., Maria, A., Michael V. Neely E. Williams Lori-Ann B. Carol B. \& Scott A. S. (2011). Biodegradation of Polyester Polyurethane by Endophytic Fungi. Applied and Environmental Microbiology, 77(17), 6076-6084.

Sagita, D. (2016). Bakteri Endofit pada Lamun di Pantai Litianak dan Oeseli, Rote Ndao, Nusa Tenggara Timur Penghasil Antibakteri terhadap Bakteri Methicillin Resistant Staphylococcus aureus (MRSA). Thesis. Surakarta: Bioscience, Universitas Sebelas Maret.

Santerre, J. P., Woodhouse, K., Laroche, G. \& Labow, R.S. (2005). Understanding the Biodegradation of Polyurethanes: from Classical Implants to Tissue Engineering materials. Biomaterials, 26, 7457-7470. 
Jurnal Biodjati 4(2):225-235, November 2019

\section{JURNAL BIDDJATI}

http://journal.uinsgd.ac.id/index.php/biodjati

Shah, Z., Lee K., Deniz F.A., Fariha H.,Mutiullah K.\& Aamer A.S.(2013). Degradation of Polyester Polyurethane by a Newly Isolated Soil Bacterium, Bacillus subtilis strain MZA-75. Biodegradation, 24, 865-877.
Whitman, W. B \& Schleifer, K. H. (2009). Bergey's Manual of Systematic Bacteriology Second Edition Volume Three. The Firmicutes. New York: Springer. 